\title{
Approved health claims for amino acids in/as food supplements
}

\author{
Ermira Krasniqi ${ }^{1,2^{*}}$, Arben Boshnjaku ${ }^{3}$, Lidija Petrusevska Tozi ${ }^{1}$ \\ ${ }^{1}$ Faculty of Pharmacy, University "Ss Cyril and Methodius", Majka Tereza 47, 1000 Skopje, Macedonia \\ ${ }^{2}$ Faculty of Medical Technical Sciences, Medical University of Tirana, Albania \\ ${ }^{3}$ University of Vienna, Faculty of Natural/Life Sciences, Vienna, Austria
}

Received: June2016, Accepted: August 2016

\begin{abstract}
Food supplements in the European Union (EU) were initially regulated by Directive 2002/46/EC, whereas in 2006, EU adopted the new Regulation on nutrition and health claims made on food - Regulation 1924/2006. Meanwhile, in the United States of America (USA), dietary supplement is defined by the congress of Dietary Supplement Health and Education Act (DSHEA, 1994).

Food supplements can be beneficial to the health of consumers, but scientific reviews of the existing data should be made by competent authorities. In Europe, a scientific review is made by European Food and Safety Authority (EFSA), the Panel of Dietetic Products, Nutrition and Allergies (NDA Panel).

Amino-acids have been the object of many scientific studies, with many of them showing their implication in health. Amino-acids carry out a big role in many body functions, cells structure, transport and storage of nutrition, leading us to the main aim of this article that is providing data related to amino-acids implication in health benefits, specifically health claims of Arginine (Erection, vascular system, muscle integrity and hematopoesis immune system function, spermatogenesis), Glutamine (intestinal health, supporting glycogen replenishment, increasing cell swelling, immune health, abundance in the body, muscle function), Lysine (cardiovascular system, increase metabolism, bones, body tissue, immune system function). Nevertheless, they don't take their credit yet and are not properly recognized in medical sciences in Europe, since the health claims of food containing amino-acids are still considered to be not established in terms of cause and effect relationship.
\end{abstract}

Keywords: health claims, amino-aids, supplements, arginine, glutamine, lysine

\section{Introduction}

\section{Regulatory Framework of Food Supplements}

Food supplements in European Union (EU) are initially regulated by Directive 2002/46/EC, according to which, a range of nutrients and other ingredients may be present in food supplements, including: vitamins, minerals, Amino acids (AA), essential fatty acids, fiber and various plants and herbal extracts (Directive 2002/46/EC). This directive in the first stage regulates nutrients as: vitamins and minerals.

In 2006 EU adopted the new Regulation on nutrition and health claims made on food - Regulation 1924/2006, which applies to nutrition and health claims made in commercial communication, labeling, presentation or advertising on foods, requiring that any health claim of food should be scientifically justified toward protection of people from any bed interpretation and information (Reg.1924/2006). Meanwhile, the Commission Regulation (EC) No 353/2008 established implementing rules for application for authorization of heath claims as provided for in Article 15 of Regulation (EC) No 1924/2006 of the European Parliament (Reg. No 353/2008).

As per the Regulation 1924/2006, there are three types of claims for the dietary supplements products that manufacturers may take: health claims, structure/function claims, nutrient content claims (Regulation 1924/2006). In

\footnotetext{
*ph.ermirakrasniqi@gmail.com
} 
the meantime, according to Article 2 (5), health claims are defined as "any claim that states, suggests or implies that a relationship exists between a food category, a food or one of its constituents and health" (Reg.1924/2006), such as immune system, muscle strength, weight loss etc.

In accordance with Article 13(1) health claims (other than those referring to the reduction of disease risk and to children`s development and health - Article 14 of the EU Regulation) are describing or referring to:

a) The role of a nutrient or other substance in growth, development and the functions of the body; or

b) Psychological and behavioral functions; or

c) Without prejudice to Directive 96/8/EC, slimming or weight-control or a reduction in the sense of hunger or an increase in the sense of satiety or to the reduction of the available energy from the diet (Regulation 1924/2006).

In Europe, a scientific review is made by European Food and Safety Authority (EFSA), the Panel of Dietetic Products, Nutrition and Allergies (NDA Panel), following the request of $\mathrm{EC}$, based on the information provided by Member States (MS) or received directly from the stakeholders. This Panel focuses on 3 criteria: Is the food or ingredient defined? Is the claimed effect defined?, What is the evidence? After the conclusion of EFSA scientific analysis (which can be negative or positive), EU and MS decides whether or not to authorize the claim.

Commission Regulation (EU) No 432/2012 of 16 May 2012 established the list of permitted health claims which may be made on foods, as referred to in Article 13(3) of Regulation (EC) No 1924/2006, in the procedure as one described above (Reg. 432/2012).

Concerning food labeling, the presentation of information and advertising must be clear, accurate and based on scientific evidence, in any way possible those information should not be misleading to the consumers.

Meanwhile, defined by the congress of Dietary Supplement Health and Education Act (DSHEA, 1994), similarly with the directive 2002/46/EC, a "dietary supplement" is a product containing a "dietary ingredient" intended to supplement the diet. A dietary ingredient in these products may include: vitamins, AA, minerals, herbs, and substances like: enzymes, organ tissues, glandular and metabolites. DSHEA places dietary supplements in a special category under umbrella "foods" not "drugs", and every supplement should be labeled a dietary supplement. This way according to FDA - DSHEA (1994) these products are not subject to pre-market safety evaluations, allowing for products labeling claims as long as it does not diagnose, prevent, treat or cure a specific disease. Manufacturers are responsible for safety evaluation and FDA's Center for Food Safety and Applied Nutrition (CFSAN) is responsible for the agency's oversight of these products. FDA is not authorized to review dietary supplement products for safety and effectiveness before they are marketed. This way, in label- ing is stated "This statement has not been evaluated by the Food and Drug Administration. This product is not intended to diagnose, treat, cure or prevent any disease" (FDA 21 CFR 101.93). According to FDA this means that there is no need for research studies in people in order to prove it safety before it is marketed. In cases when dietary supplements contain new dietary ingredient, must notify FDA at least 75 days before introducing the dietary supplement into commerce and provide FDA with information that is the basis upon which the manufacturer has concluded that the dietary supplement with reasonably be expected to be safe (DSHEA of 1994. P.L. 103-417) but this is not a premarket approval process.

Dietary supplements can be found in different forms, such as: tablets, capsules, soft gels, gel caps, liquids, and powders.

\section{Methodology}

In order to explore the current state of knowledge and the international policies regarding health claims of AA as dietary ingredient of dietary supplements in general, focusing in AA: arginine, glutamine and lysine in particular, we performed a literature review within the major scientific databases such as Pubmed (Medline), database for English language articles published up to the time when this study was performed (February, 2016). Together with that, databases of EFSA's Register of Questions, database of health claims submitted to EFSA for evaluation, detailed scientific opinions of NDA on the substantiation of health claims, as requested by European Commission, regarding the above mentioned AA uses and benefits were analyzed. Additionally, these data's were supplemented with extra resources of information from google scholar and google search engine, with interesting information from government databases and guidance's from different government agencies, non-governmental organizations, previous, current and planned legislative on the topic etc.

The literature review together with the structured internet search was conducted from December 2015 to February 2016.

\section{Results and discussion}

AA are organic compound containing amine $\left(-\mathrm{NH}_{2}\right)$ and carboxylic acid $(-\mathrm{COOH})$ functional groups, with the key elements: carbon, hydrogen, oxygen, and nitrogen (Wu, 2009).

Of the 20 standard AA, 9 are called essential AA (histidine, isoleucine, leucine, lysine, methionine, phenylalanine, threonine, tryptophan, valine) because the human body cannot synthesize them from other compounds at the level needed for normal growth, so they must be obtained from food (Michael, 1997). In addition, cysteine, taurine, tyrosine, and arginine are considered semi essential ami- 
no-acids in children (though taurine is not technically an amino acid), because the metabolic pathways that synthesize these AA are not fully developed (Michael, 1997). And nonessential AA (alanine, asparagine, aspartic acid, glutamic acid, glutamine, glycine, proline, selenocysteine, serine, tyrosine) (Michael, 1997).

AA make up a big part of cells, muscle and tissue, this way carrying out a big role in many body functions, cells structure, transport and storage of nutritious (Lupi et al., 2008). The amounts required also depend on the age and health of the individual, so it is hard to make general statements about the dietary requirement for some $\mathrm{AA}(\mathrm{Wu}$, 2009). For example, the requirement for essential AA in neonates is larger than that in adults (Imura et al., 1998). Different researches over years, claim for the possibility of useful of AA against osteoporosis, diabetes, heart trouble, metabolic disorders, erectile dysfunction, menopausal complaints etc (Ardawi et al., 1983; Braga et al., 1999; Civitelli et al 1992; Grillo et al., 2004; Morris, 2006; Piatti et al., 2001; Raghavan et al., 2004; Rassaf et al., 2006; Welbourne, 1995).

AA that will be analyzed in details in this paper are: Arginine (conditionally essential amino acid in humans) (Böger and Bode-Böger, 2001), Glutamine (non-essential and conditionally essential in humans) (Brosnan, 2003), Lysine (an essential amino acid in humans, meaning the body cannot synthesize it so it has to be obtained from the diet) (Flodin, 1997). Among other AA (cysteine, glycine, and methionine, taurine), arginine, glutamine and lysine may be beneficial for people with immunodeficiency ( $\mathrm{Li}$ et al., 2007; Suenaga et al., 2008; Wu et al., 1996a, 1996b).

\section{Arginine}

Arginine (or L-arginine as it is called with its L-structure) (Fig. 1) is a semi-essential, alpha - amino acid. Lform is most commonly found form in nature and in food supplements. L-arginine, as a food constituent, is the subject of the health claims, and is considered to be sufficiently characterized.

L-Arginine (2-amino-5-guanidinovaleric acid) is the precursor of nitric oxide, an endogenous messenger molecule involved in a variety of endothelium-mediated physiological effects in the vascular system (Böger and BodeBöger, 2001).

Generally speaking Arginine is involved in many metabolic processes and many studies so far argue for its importance in heart disease and high blood pressure, improvement of circulation, strengthening of immune system and a positive influence on male libido (Bronte et al., 2005; Wu et al. 2008).

Regarding the possibility of side effects, arginine supplementation is considered safe, people with renal failure or hepatic disease may be unable to appropriately metabolize and excrete supplemental arginine, this way they should be monitored (AMR, 2005). Based in vitro data ar-

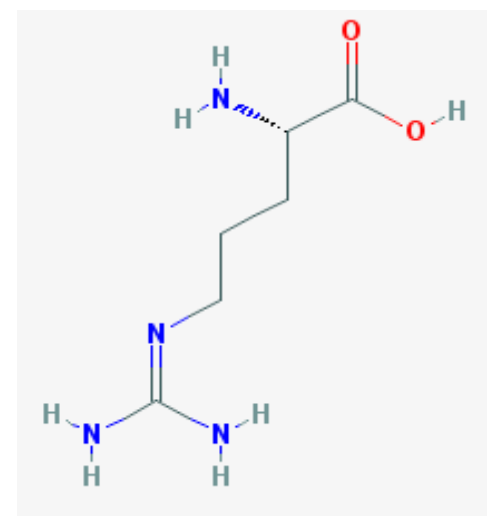

Fig. 1. Structure of Arginine (Ref. PubChemhttps: //pubchem. ncbi.nlm.nih.gov/compound/6322\#section=Top).

ginine supplementation might be contradicted in person with herpes infections (Tankersley, 1964).

Referring to many studies, research and experience with arginine, below are listed Health Claims of arginine as food supplement:

\section{L-Arginine}

1. Health Relationship: Erection

Claim: L-arginine helps to induce and improve erection.

Condition for use: $500 \mathrm{mg}$ for 8 weeks.

\section{Health Relationship: Spermatogenesis}

Claim: Influence positively on spermatogenesis (sperms formation and mobility).

Condition for use: $500 \mathrm{mg}$ for 3 months.

3. Health Relationship: Vascular system; (blood pressure, circulation, vessels). (Grillo et al., 2004; Morris, 2006; Raghavan et al., 2004; Rassaf et al., 2006); Vascular health/Blood circulation (Boger and Ron, 2005; Gornik and Creager, 2004; Siani et al., 2000).

Claim: Arginine can contribute to the maintenance of the healthy blood circulation. Support of normal blood circulation. Arginine is the precursor of nitric oxide, a molecule which in turn plays a key role in the regulation of blood circulation via its effects on blood vessels. Arginine supports a normal blood circulation.

Condition for use: $225 \mathrm{mg}$ daily; (15\% of the lower (1500 mg) therapeutic dose $1500 \mathrm{mg}$ per day, $75-150 \mathrm{mg}$.

According to Scientific opinion of EFSA - NDA Panel for Health Claims of L-arginine (EFSA, 2011) the claimed effects "erection" and "supporting spermatogenesis" for the target population male population, the Panel assumes that that claimed effects referee to the maintenance of normal erectile function is beneficial physiological effect. In 
the other hand referring to two human intervention studies of investigating the effect of L-arginine consumption on erectile dysfunction and one human intervention study the Panel concluded that there is no cause-effect relationship established.

According to Scientific opinion of EFSA - NDA Panel for Health Claims of L-arginine (EFSA, 2011) the claimed effect "vascular system": normal blood pressure is considered form the Panel to be a beneficiary physiological effect, improvement of endothelium-dependent vasodilation form the Panel is considered that may be a beneficial physiological effects and normal red blood cell formation is beneficial physiological effect.

According to the Natural Medicines Comprehensive Database (NMCD), Arginine is possible effective for: Improvement of symptoms of people with angina (but not the disease itself); high blood pressure; Increases blood flow in people with peripheral arterial disease (if taken for more than 8 weeks); erectile dysfunction (if taken $5 \mathrm{~g}$ daily); and if taken with ribonucleic acid (RNA) and eicosapentaenoic acid (EPA) before the surgery or afterwards seems to improve wound healing after the surgery (NLM L-arginine, 2016).

\section{Arginine}

1. Health Relationship: For muscle integrity and hematopoiesis (red blood cells building)

Claim: It has positive effects on muscle integrity and on haematopoiesis (for red blood cells building).

Condition for use: $75-150 \mathrm{mg}$.

2. Health Relationship: For immune system functions (Arginine is necessary for the synthesis of proteins within the body tissues (it supports tissue repair and growth acceleration), it plays an important role in cell division and is necessary for the proper functioning of the immune system, by accelerating wounds healing) (Brag et al.,1999).

Claim: Essential amino acid that plays an important role in the immune system (Conditionally-essential amino acid that plays an important role in the growth and immune system, It supports tissue growth acceleration).

According to a research (Böger and Bode-Böger et al., 2001), the mechanism of action of L-arginine may involve Nitric Oxide (NO) synthase substrate provision, especially in patients with elevated levels of the endogenous NO synthase inhibitor asymmetric dimethyl arginine, since acute and chronic administration of L-arginine has been shown to improve endothelial function in animal models of hypercholesterolemia and atherosclerosis. Additionally, L-arginine also improves endothelium-dependent vasodilation in humans with hypercholesterolemia and atherosclerosis (Böger and Bode-Böger, 2001). Side effects are rare and mostly mild and dose dependent. Another research in gilts and sows (Li et al., 2015) indicate that dietary arginine supplementation during early gestation improves the reproductive performance of gilts and sows, possibly via nitric oxide and polyamine-dependent mechanisms. Arginine appears to be safe and effective therapy for many health conditions, particularly vascular diseases responsive to modulation of endothelial-derived relaxing factor including intermittent claudication, angina pectoris and erectile dysfunction but still its metabolism is still not fully understood (Calabrò et al., 2014).

L-arginine is converted in the body into chemical called nitric oxide, which causes blood vessels to open wider for improved blood flow.

Although, on the Request of EC, NDA Panel provided a Scientific Opinion on a list of health claims pursuant to Article 13 of Regulation (EC) No 1924/2006 (EFSA, 2011) L-arginine is considered to be sufficiently characterized and regarding the claimed effects are considered general and non-specific, apart from the role of arginine contributing to protein synthesis.

In meantime, referring to U.S. National Library of Medicine (NIH), possible effectiveness of L-arginine relies on: Erectile dysfunction (taking $5 \mathrm{~g}$ by mouth daily), high blood pressure (early evidences) and high blood pressure during pregnancy (although further analyses must be made), as well as leg pain associated with poor blood flow (taking IV or by mouth for up to 8 weeks increases blood flow in people with peripheral arterial diseases) (NLM Larginine, 2016).

There are also studies that gives information regarding the possibility of the treatment with L-Arginine and significantly improvement of peripheral and hepatic insulin sensitivity in type 2 diabetic patients, but not completely normalizing it, acting through of normalization $\mathrm{NO} / \mathrm{cy}$ clic-guanosine-3' 5'-cyclic monophosphate (cGMP) pathway (Piatti et al., 2001).

\section{Glutamine}

Glutamine (Fig. 2) is an alpha amino acid, natural occurring nonessential neutral amino acid, containing an alpha-amino group (which is in the protonated -+NH3 form under biological conditions) and alpha-carboxylic acid group (which is in the deprotonated -COO- form under biological conditions).

In human blood, glutamine is the most abundant free amino acid, with a concentration of about $500-900 \mu \mathrm{mol} / 1$ (Antonio and Street, 1999; Brosnan, 2003). In adults, normal plasma glutamine concentration is $550-750 \mu \mathrm{mol} / 1$ and in skeletal muscle is $20 \mathrm{mmol} / \mathrm{kg}$ wet weight (Jonnalagadda, 2007). 


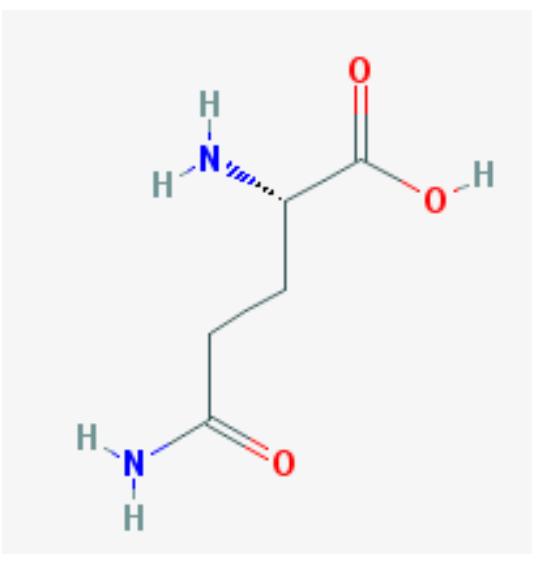

Fig. 2. Structure of Glutamine (Ref. PubChem: https://pubchem.ncbi.nlm.nih.gov/ compound/5961\#section=Top).

Human body produces L-glutamine itself, from L-glutamic acid through the glutamate ammonium ligase, the production often slows down with age and does not generate sufficient amount, in which cases sufficient amount is recommended. Its highest concentration is in blood plasma, musculature, cerebral and spinal fluid. The demand for glutamine increases with physical and mental stress.

Glutamine is important as a constituent of proteins, means of nitrogen transport between tissues (Watford, 2008), important in acid base regulation, gluconeogenesis, as a precursor of nucleotide bases and the antioxidant glutathione. Also glutamine is considered important in proliferation of lymphocytes and other rapidly dividing cell, including the gut mucosa and bone marrow stem cells (Ardawi et al., 1983; Souba, 1992).

Clinical trials in humans show that the administration of glutamine is well tolerated and without side effects (AMR, 2001). According to actual recommendation, dosages vary depending on the clinical situation, in cases of wound healing and intestinal support, the recommended dose is 2 to $4 \mathrm{~g}$ daily in divided doses, in meantime in cases of cancer, HIV patients, critically ill adults the dose is recommended from 10-40 $\mathrm{g}$ daily in divided doses (AMR, 2001). Many researches suggest that glutamine may provide benefit for surgery, trauma, help support digestive system health after periods of physical stress (Newsholme et al., 2003; Shils et al., 2006; Trumbo et al., 2002), wound healing, helps support immune system health after periods of physical stress (Griffiths, 1999; Newsholme, 2001; Shils et al., 2006), helps to assist in muscle cell repair after exercise (Newsholme et al., 2003; Trumbo et al., 2002) HIC/ AIDS, cancer and bone marrow transplantation, however below we have data if these claims are approved from official regulatory authorities.

Today, pharmaceutical dosage forms include, but not are not limited to capsules, chewable, liquid, powders, strips or tablets, not in liquid or/and solutions due to its in- stability (Fürst et al., 1997).

Referring to many studies, research and experience with glutamine, below are listed Health Claims of glutamine as food supplement:

1. Health Relationship: Immune Health

Claim: To support the body's defense system. To support immune system. To enhance organism resistance.

Condition for use: $50-400 \mathrm{mg} / \mathrm{kg}$ per day.

\section{Health Relationship: Intestinal Health}

Claim: Glutamine helps promote and maintain integrity of the intestinal lining. Glutamine may help prevent intestinal permeability. Glutamine may help support a healthy gastro-intestinal tract.

Condition for use: A stimulatory effect has been noted at high doses, some people may experience diarrhea at high doses.

3. Health Relationship: Supporting glycogen replenishment

Claim: Glutamine may support muscle glycogen replenishment following exhaustive exercise.

Condition for use: Amount of consumption (value): 50 $\mathrm{mg}$. Amount of consumption (plaintext): $\mathrm{mg} / \mathrm{kg} \mathrm{KG} \mathrm{p}$. day. Upper limit (value): $900 \mathrm{mg}$. Other condition: $\mathrm{mg} / \mathrm{kg}$ daily - The product must contain at least $5 \mathrm{~g}$ Glutamine per serving. Claim to be used for foods for active individuals.

\section{Health Relationship: Muscle function}

Claim: Increases blood glutamine levels, which is reduced during exercise (Walsh et al.,1998).

Condition for use: $50-900 \mathrm{mg} / \mathrm{kg}$ per day.

According to Scientific opinion of EFSA-NDA Panel for Health Claims of glutamine (EFSA, 2009) health claims such as "immune health" and "intestinal health". Referring to the Panel, claimed effect "immune health" is general and not-specified, meanwhile claimed effect "intestinal health" is not well specified but assuming that the claimed effect referees to "maintaining the integrity of intestinal permeability" is beneficial to human health.

According to Scientific opinion of EFSA-NDA Panel for Health Claims of glutamine (EFSA, 2011a) the health claim referees to faster restoration of glycogen stores in skeletal muscle after strenuous exercise, which the Panel considers that might be a beneficial physiological effect. But, based on scientific data the Panel concludes the relationship of cause and efficacy of the claimed effect has been established.

According to Scientific opinion of EFSA-NDA Panel for Health Claims of glutamine (EFSA, 2011a) the claimed effect "increasing cell swelling, volumization", "muscle protein metabolism" and "improves muscles metabolism" referee to the growth or maintenance of muscle mass which by the Panel are considered to be of a beneficial physiological effects. And according to the Panel the cause and ef- 
fects relationship has not been established of L-glutamine and growth of maintenance of muscle mass apart from this approved claim of protein.

\section{Health Relationship: Mental health}

Claim: Constituent of glutathione, purines, amino sugars, precursor of GABA (g-amino butyric acid)/supports concentration and mental performance under conditions of mental or physical exertion/ helps to maintain working memory and brain performance in aging adults/plays an important role in healthy nerve function through the central nervous system including the brain.

Condition for use: Min $100 \mathrm{mg}$ per day.

6. Health Relationship: Increases blood glutamine levels, which is reduced during exercise

Claim: Skeletal muscle represents the greatest store of glutamine in the body/muscle tissue is an important source of glutamine/high intensity exercise decreases plasma glutamine levels anaerobic training can deplete the glutamine pool/prolonged exercise such as marathon running decreases glutamine levels/supplementation can maintain glutamine levels during intense exercise/can abolish the exercise related decline restores blood glutamine levels post exercise/helps maintain optimal health after training/ helps keep athletes healthy after intense exercise/optimizing blood glutamine levels helps enhance muscle adaptation to intense exercise /reduced glutamine levels decreases the adaptive response to intense exercise/helps enhance glycogen storage/helps increase carbohydrate storage.

7. Health Relationship: Increasing cell swelling / volumization.

Claim: Glutamine may improve intestinal water and electrolyte absorption. Glutamine can help volumize muscle cells. Glutamine may increase cell swelling (volume).

8. Health Relationship: Abundance in the body.

Claim: Glutamine is the most abundant amino acid in the human body. Glutamine is the most abundant free amino acid in human muscle and plasma.

Conditions of use: The product must contain at least 5 g Glutamine per serving.

Claim: to be used for foods for active individuals.

9. Health Relationship: Supporting exercise recovery

Claim: Glutamine is considered essential for repair and recovery.

Glutamine can aid In muscle tissue repair.

Conditions of use: The product must contain at least 5 g Glutamine per serving.

Claim: to be used for foods for active individuals.

Generally speaking, prolonged exercise and periods of heavy training are associated with decrease in the plasma glutamine concentration, which is suggested to be a po- tential cause of the exercise -induced immune impairment and increased the possibility of infections in athletes. This may be in correlation with the fact that glutamine is essential for lymphocyte proliferation, even though it is not well established if level of decrease of the plasma level is as much as it the level of glutamine needed for a normal lymphocyte proliferation needed. (Gleeson, 2008).

There are also studies showing the impact of oral glutamine load in elevating alkaline reserves and plasma growth hormone (Welbourne, 1995).

Although, on the Request of EC, - NDA Panel provided a Scientific Opinion on a list of health claims pursuant to Article 13 of Regulation (EC) No 1924/2006 (EFSA, 2011a), L-glutamine (as the food constituent that is the subject of health claim) is considered to be sufficiently characterized and regarding the claimed effects, referring to all the data presented are considered general and nonspecific, apart from the role of glutamine contributing to protein synthesis.

Lysine

Lysine (Fig. 3) is essential in humans, meaning the body cannot synthesize it so it has to be obtained from the diet. Lysine can also be consumed in the form of food supplements as L-lysine. L-lysine as food constituent, which is a subject of the health claims, form the Panel of NDA is considered to be sufficiently characterized.

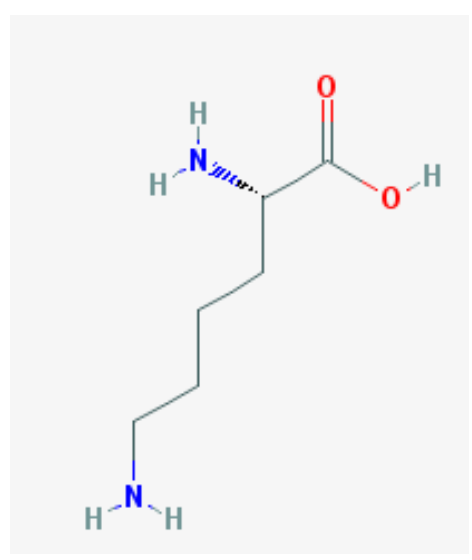

Fig. 3. Structure of Lysine (Ref. Pub Chem: https://pubchem.ncbi.nlm.nih.gov/ compound/5962\#section=Top)

Lysine is transported into muscle tissue and is more concentrated in the intracellular space of muscle tissue compared to other essential AA (Flodin, 1997; Longenecker and Hause, 1959).

Regarding mechanism of action, lysine is converted to acetyl $\mathrm{CoA}$, a critical component in carbohydrate metabolism and the production of energy. Lysine is precursor of the carnitine, which is transporting long-chain fatty acids into the mitochondria for energy production (Bro- 
quist, 1982).

As per physiological requirements, in a $70 \mathrm{~kg}$ adult it is accepted in the range of 800-3000 $\mathrm{mg} /$ day (Meredith et $\mathrm{al}, 1986$ ). Higher doses (such as $>10-15 \mathrm{~g}$ ) daily may be associated with side effects such as abdominal cramps, nausea, diarrhea, nausea (PDRhealth, 2007). In market can be found as food supplement in unit description such as: 75 $\mathrm{mg}$ inhaler solution, $500 \mathrm{mg}$ tablet, $1000 \mathrm{mg}$ tablet, ointment, powder (DrugBank, 2016). L-lysine supplementation should be used after consultation with e healthcare practitioner by individuals with history of hepatic or renal failure because much of lysine catabolism occurs in the liver (AMR, 2007).

Referring to many studies, research and experience with lysine, below are listed Health Claims of lysine as food supplement:

1. Health Relationship: For immune systems functions (Lysine is necessary for proper functioning of the immune system, for helping produce antibodies that are necessary for warding off infections).

Claim: Lysine supports the immune systems functions.

Conditions of use: $50-500 \mathrm{mg}$, in general for groups with insufficient intake of animal proteins - day dozes LLysin as Lysin HCL: $500 \mathrm{mg}$-Erwachsene-Tagesdosis LLysin als L-Lysin $\mathrm{HCl}: 500 \mathrm{mg}-$ Erwachsene.

2. Health Relationship: For cardiovascular system functions (Lysine helps proper blood circulation, by helping to release fats that are deposited in blood vessels walls).

Claim: Lysine supports the cardiovascular system functions.

Conditions of use: $50-500 \mathrm{mg}$, in general for groups with insufficient intake of animal proteins.

3. Health Relationship: Body tissues (Increases protein utilization in people with low protein intake OR Lysine is necessary for the synthesis of proteins within the tissues of the body (collagen, teeth, bones and muscles). It increases absorption, action and conservation of calcium in muscles, bones and teeth).

Claim: Lysine is an essential amino acid that is necessary for maintenance of the body/body tissues/body function -addition of lysine enhances of cereal protein quality. Increases absorption, action and fixation of calcium, essential for optimal muscle, bone and teeth.

Conditions of use: $50-500 \mathrm{mg}$, in general for groups with insufficient intake of animal proteins.

4. Health Relationship: To increase metabolism (Lysine is necessary for proper liver function, to produce carnitine, which is necessary for transporting and converting fatty acids into energy. Lysine helps to naturally stimulate the appetite, by supporting a proper body metabolism. If there is too little lysine in the diet, loss of appetite may occur.)

Claim: It improves liver function. To stimulates the appetite in a natural way.

Conditions of use: $50-500 \mathrm{mg}$, in general for groups with insufficient intake of animal proteins.

\section{L-Lysine}

1. Health Relationship: Bones.

Claim: Lysine can contribute to the development and maintenance of the normal structure of bones.

Conditions of use: the daily dose is $12 \mathrm{mg} / \mathrm{kg}$ recommended by $\mathrm{FAO} / \mathrm{WHO} / \mathrm{UNU}$ report 1985 (Food and Agriculture Organization/ World Health Organization/United Nation University). This equals to $840 \mathrm{mg}$ for an average person of $70 \mathrm{~kg}$ (FAO/WHO/UNU. 1985).

Firstly, L-lysine, which is the subject of the health claims, is sufficiently characterized as per scientific evaluation of The Panel. According to studies, supplemental Llysine has putative anti-herpes simplex virus activity (Miller and Foulke, 1984), however by the Panel (2011) is not considered yet a well-established of cause and effect relationship, as it is described below. This, also because lysine seems to have an antagonist effect with arginine, which is required for the replication of HSV (Griffith, 1981).

According to Scientific opinion of EFSA -NDA Panel for Health Claims of L-lysine maintenance of bone is considered by the Panel to be a beneficial physiological effect, but the Panel (2011) concludes that the relationship between cause and effect has not yet been established. Also, health claim increase in calcium retention and increase in calcium absorption leading to an increase in calcium retention, the Panel considered that may be a beneficial physiological effect but the cause effect relationship has not been established (EFSA, 2011b). Studies have shown that Llysine can both enhance intestinal $\mathrm{Ca}$ absorption and improve the renal conservation of the absorbed $\mathrm{Ca}$, which shows that this can contribute to a positive $\mathrm{Ca}$ balance, suggesting a potential use of L-lysine supplements for preventive and therapeutic intervention in osteoporosis (Civitelli et al., 1992). Lysine can also block the absorption of the amino acid arginine in the cells, allowing more arginine to be contained in blood plasma (Torricelli et al., 2002).

Other L-lysine health claims, such as: "immune defense against herpes virus", "maintenance of normal blood LDL-cholesterol concentrations", "increase in appetite leading to an increase in energy intake", "contribution to normal protein synthesis" are claims that according to the Scientific Opinion of EFSA NDA Panel are or might be of a beneficial physiological effect and assessed with a favorable outcome but the Panel concluded that a cause and effect relationship has not been established on the basis of data presented (EFSA, 2011b). 
Specifically, data presented for the health claim "contribution to normal protein synthesis" indicate that the supplementation of a food deficient in one or more indispensable amino acid(s) will raise the nutrient value of the protein. However there was no specific reference for the effect of L-lysine specifically.

There are also health claims related to vitamins, minerals, lysine and/or arginine and/or taurine. Scientific opinion of EFSA NDA Panel for the claims "nutritional support during the period of growth for physical activity development", "nutritional support after illness" and "nutritional support to help mental performance" of the food firstly relies in the fact that a food containing this combination is not sufficiently characterized in relation to the claimed effects. The Panel also concludes that a cause and effect relationship cannot be established between the use of the food containing the combination: vitamins, minerals, lysine and/or arginine and/or taurine and claimed effects due to lack of full scientific evidence (EFSA,2011c), with the specific dosage combination listed below:

For the claimed effect claims "nutritional support during the period of growth for physical activity development":

- Multivitamin/mineral products containing the following dosage range: Betacarotene: 0.514-1.6 mg, Vitamin A: 715-2145 IU, Vitamin B1: 0.5-3 mg, Vitamin B2: $0.55-3.5 \mathrm{mg}$, Vitamin B6: 0.55-6 mg, Vitamin B12: $0.6-1.8 \mathrm{mcg}$, Vitamin C: $22-66 \mathrm{mg}$, Vitamin D3: $150-600 \mathrm{IU}$, Vitamin E: $3.5-15 \mathrm{mg}$, Folic acid: 0.05-0.15 mg, Biotin: 15-45 mcg, Vitamin PP (nicotinamide): 6-20 mg, Dexpanthenol: 5-10 mg, Copper: 0.3-0.9 mg, Calcium: 65-200 mg, Phosphorus: 100$200 \mathrm{mg}$, Iron: $2.5-7.5 \mathrm{mg}$, Zinc: $2.5-7.5 \mathrm{mg}$, Magnesium: 12.5-40 mg, Manganese: $0.5 \mathrm{mg}$ ), Lysine (50$500 \mathrm{mg} /$ day), and/or Arginine (75-150 mg/day) and/or Taurine ( $75-150 \mathrm{mg} /$ day).

For the claimed effect claims "nutritional support after illness":

- Multivitamin/mineral products containing the following dosage range: Betacarotene: 0.514-1.6 mg, Vitamin A: 715-2145 IU, Vitamin B1: 0.5-3 mg, Vitamin B2: 0.55- $3.5 \mathrm{mg}$, Vitamin B6: 0.55-6 mg, Vitamin B12: 0.6-1.8 mcg, Vitamin C: 22-66 mg, Vitamin D3: 150600 IU, Vitamin E: $3.5-15 \mathrm{mg}$, Folic acid: 0.05-0.15 $\mathrm{mg}$, Biotin: $15-45 \mathrm{mcg}$, Vitamin PP (nicotinamide): 6-20 mg, Dexpanthenol: 5-10 mg, Copper: 0.3-0.9 mg, Calcium: $65-200 \mathrm{mg}$, Phosphorus: 100-200 mg, Iron: 2.5-7.5 mg, Zinc: 2.5-7.5 mg, Magnesium: 12.5$40 \mathrm{mg}$, Manganese: $0.5 \mathrm{mg}$, Lysine $(50-500 \mathrm{mg} /$ day) and/or Arginine (75-150 mg/day) and/or Taurine (75$150 \mathrm{mg} /$ day)

For the claimed effect claims "nutritional support to help mental performance":

- Multivitamin/mineral products containing the following dosage range: Betacarotene: 0.514-1.6 mg, Vitamin A: 715-2145 IU, Vitamin B1: 0.5-3 mg, Vitamin B2:
0.55- $3.5 \mathrm{mg}$, Vitamin B6: 0.55-6 mg, Vitamin B12: 0.6-1.8 meg, Vitamin C: 22-66 mg, Vitamin D3: $150-$ 600 IU, Vitamin E: 3.5-15 mg, Folic acid: 0.05-0.15 $\mathrm{mg}$, Biotin: $15-45 \mathrm{mcg}$, Vitamin PP (nicotinamide): 6-20 mg, Dexpanthenol: 5-10 mg, Copper: 0.3-0.9 $\mathrm{mg}$, Calcium: 65-200 mg, Phosphorus: 100-200 mg, Iron: 2.5-7.5 mg, Zinc: 2.5-7.5 mg, Magnesium: 12.5 $40 \mathrm{mg}$, Manganese: $0.5 \mathrm{mg}$, Lysine $(50-500 \mathrm{mg} /$ day $)$ and/or Arginine (75-150 mg/day) and/or Taurine (75$150 \mathrm{mg} / \mathrm{day})$.

However, L-lysine is available as a nonprescription oral supplement. Most of the pharmaceutical grade product is used as a suppressant of recurrent herpes simplex infections.

\section{Conclusion}

All the data summarized above, suggest that food supplements in general and AA in particular can be beneficial to the health of consumers, but a scientific review of the existing data should be made by competent authorities. In addition to that it should be noted that food supplements cannot be excluded from the possibility of side effects. In general, EFSA finished the scientific evaluation of the "general function" health claims by the end of June, 2011.

Being part of many metabolic processes, AA particularly have been object of many scientific studies and there are many ongoing studies and researches showing their efficacy in different conditions, such as: diabetes, depression, osteoporosis, heart attacks, fat metabolism, compromised immune system and erectile dysfunction. Nevertheless, they don't take their credit yet and are not properly recognized in medical sciences in Europe, since the health claims of food containing AA are considered to be sufficiently characterized, but regarding their claimed effects are not established in terms of cause and effect relationship. Therefore, analyzing all the publications in this direction, the faster this process goes, the greater will be the chances for health benefits amongst population in relation to AA uses, since they hold great opportunities regarding health improvement.

As it is well said "Few issues in nutritional science have aroused such long-standing and deep-seated controversies as protein and amino acid requirements?" (Millward et al., 1997).

\section{Declaration of interests}

The authors report that they have no competing interests. 


\section{References}

AMR, L-Glutamine monograph, 2001. Altern. Med. Rev. 6(4), 406-410.

AMR, L-Arginine. 2005. Altern. Med. Rev. 10(2), 139-147.

AMR, 1-Lysine. 2007. Altern. Med. Rev. 12(2), 169-172.

Antonio, J., and Street, C., 1999. Glutamine: A potentially useful supplement for athletes. Can. J. Appl. Physiol. 24(1), 1-14.

Ardawi, M.S., Newsholme, E.A., 1983. Glutamine metabolism in lymphocytes of the rat. Biochem. J. 212, 835-842.

Böger, R.H., Bode-Böger, S.M., 2001. The clinical pharmacology of L-arginine. Annu. Rev. Pharmacol. Toxicol. 41, 79-99.

Boger, S.H., Ron, S.E., 2005. L-Arginine improves vascular function by overcoming deleterious effects of ADMA, a novel cardiovascular risk factor. Altern. Med. Rev. 10, 14-23.

Braga, M., Gianotti, L., Radaelli, G., Vignali, A., Mari, G., Gentilini, O., Di Carlo, V., 1999. Perioperative Immunonutrition in Patients Undergoing Cancer Surgery Results of a Randomized Double-blind Phase 3 Trial. Arch. Surg. 134(4), 428-433. doi:10.1001/archsurg.134.4.428.

Bronte, V, Zanovello, P., 2005. Regulation of immune responses by L-arginine metabolism. Nat. Rev. Immunol. 5, 641-654.

Broquist, H.P., 1982. Carnitine biosynthesis and function. Introductory remarks. Fed. Proc. 41, 2840-2842.

Brosnan, JT., 2003. Interorgan Amino Acid Transport and its Regulation. J. Nutr. 133(6), 2068S-2072S.

Calabrò, R.S., Gervasi, G., Bramanti, P., 2014. L-Arginine and vascular diseases: lights and pitfalls. Acta Biomed. 85(3), 222-228

Civitelli, R., Villareal, D.T., Agnusdei, D., Nardi, P., Avioli, L.V., Gennari, C., 1992. Dietary L-lysine and calcium metabolism in humans. Nutrition 8(6), 400-405.

Commission regulation (EC) No 353/2008, 2008. Establishing implementing rules for applications for authorisation of health claims as provided for in Article 15 of Regulation (EC) No 1924/2006 of the European Parliament and of the Council. OJ L109, 11-16.

Commission regulation (EU) No 432/2012, 2012. Establishing a list of permitted health claims made on foods, other than those referring to the reduction of disease risk and children `s development and health. OJ L136, 1-40.

DrugBank http://www.drugbank.ca/drugs/DB00123 [Accessed 15/08/2016].

DSHEA (Dietary Supplement Health and Education Act of 25 October 1994), 1994. Food and Drug Administration (FDA), 30 Public Law. 103-417.

EFSA, 2009. Scientific opinion on the substantiation of health claims related to glutamine and immune health (ID 733) and integrity of the intestinal lining and normal intestinal permeability (ID 1602) pursuant to Article 13(1) of Regulation (EC) No 1924/2006. EFSA Journal 7(9), 1235.

EFSA, 2011. Scientific opinion on the substantiation of health claims related to L arginine and "immune system functions" (ID 455, 1713), growth or maintenance of muscle mass (ID 456,1712 , 4681), normal red blood cell formation (ID 456, $664,1443,1712$ ), maintenance of normal blood pressure (ID 664, 1443), improvement of endothelium-dependent vasodilation (ID 664, 1443, 4680), "physical performance and condition" (ID 1820), "système nerveux" (ID 608), maintenance of normal erectile function (ID 649, 4682), contribution to normal spermatogenesis (ID 650, 4682), "function of the intestinal tract" (ID 740), and maintenance of normal ammonia clearance (ID 4683) pursuant to Article 13(1) of Regulation (EC) No 1924/2006. EFSA Journal 9(4), 2051.

EFSA, 2011a. Scientific opinion on the substantiation of health claims related to L-glutamine and growth or maintenance of muscle mass (ID 719, 722, 3185), faster restoration of muscle glycogen stores after strenuous exercise (ID 434, 699, 701, 723, 1569), skeletal muscle tissue repair (ID 721), maintenance of normal neurological function (ID 662, 700), increased attention (ID 700, 1570), improvement of working memory (ID 700, 1570), maintenance of defence against pathogenic gastro-intestinal microorganisms (ID 452), gut protein synthesis (ID 701), decreasing gut permeability (ID 701), and stimulating immunological responses (ID 1568) pursuant to Article 13(1) of Regulation (EC) No 1924/2006. EFSA Journal 9(6), 2225.

EFSA, 2011b. Scientific opinion on the substantiation of health claims related to L-lysine and immune defence against herpes virus (ID 453), maintenance of normal blood LDLcholesterol concentrations (ID 454, 4669), increase in appetite leading to an increase in energy intake (ID 610), contribution to normal protein synthesis (ID 609, 1612), maintenance of normal bone (ID 663, 1915), and increase in calcium absorption leading to an increase in calcium retention (ID 609, 1612) pursuant to Article 13(1) of Regulation (EC) No 1924/2006. EFSA Journal 9(4), 2063.

EFSA, 2011c. Scientific opinion on the substantiation of health claims related to: anthocyanidins and proanthocyanidins (ID $1787,1788,1789,1790,1791)$; sodium alginate and ulva (ID 1873); vitamins, minerals, trace elements and standardised ginseng G115 extract (ID 8, 1673, 1674); vitamins, minerals, lysine and/or arginine and/or taurine (ID 6, 1676, 1677); plant-based preparation for use in beverages (ID 4210, 4211); Carica papaya L. (ID 2007); "fish protein" (ID 651); acidic water-based, non-alcoholic flavoured beverages containing calcium in the range of 0.3 to $0.8 \mathrm{~mol}$ per mol of acid with a $\mathrm{pH}$ not lower than 3.7 (ID 1170); royal jelly (ID 1225, 1226, 1227, 1228, 1230, 1231, 1326, 1328, 1329, 1982, 4696, 4697); foods low in cholesterol (ID 624); and foods low in trans-fatty acids (ID 672, 4333) pursuant to Article 13(1) of Regulation (EC) No 1924/2006. EFSA Journal 9(4), 2083.

$\mathrm{FAO} / \mathrm{WHO} / \mathrm{UNU}, 1985$. Energy and protein requirements. Report of a joint $\mathrm{FAO} / \mathrm{WHO} / \mathrm{UNU}$ expert consultation. Geneva: World Health Organization.

FDA 21 CFR 101.93; Volume 2, Chapter I, Subchapter B, Part 101 - Food Labeling.

Flodin, N.W., 1997. The metabolic roles, pharmacology, and toxicology of lysine. J. Am. Coll. Nutr. 16, 7-21.

Food Supplements Directive 2002/46/EC of the European Parliament and the Council of 10 June 2002.

Fürst, P., Pogan, K., Stehle, P., 1997. Glutamine dipeptides in clinical nutrition. Nutrition 13(7-8), 731-737.

Gleeson, M., 2008. Dosing and Efficacy of Glutamine Supplementation in Human Exercise and Sport Training, The Journal of Nutrition, $7^{\text {th }}$ Amino Acid Assessment Workshop. 138, 2045S-2049S.

Gornik, H.L., Creager, M.A., 2004. Arginine and endothelial and vascular health. J. Nutr. 134, 2880S-2887S.

Griffith, R.S., DeLong, D.C., Nelson, J.D., 1981. Relation of arginine-lysine antagonism to Herpes simplex growth in tissue culture. Chemotherapy 27, 209-213.

Griffiths, R.D., 1999. Glutamine: establishing clinical indications. Current Opinion in Clinical Nutrition and Metabolic Care 2(2), 177-182. 
Grillo, M.A., Colombatto, S., 2004. Arginine revisited: mini review article. Amino Acids 26(4), 345-351.

Imura, K., Okada, A., 1998. Amino acid metabolism in pediatric patients. Nutrition 14(1),143-148.

Jonnalagadda, S.S., 2007. Glutamine. In: Driskell, J.A. (Eds.), Sports nutrition: fats and proteins. CRC Press, Boca Raton (FL), pp. 261-277.

Li, J., Xia, H., Yao, W., Wang, T., Li, J., Piao, X., Thacker, P., Wu, G., Wang, F., 2015. Effects of arginine supplementation during early gestation (day 1 to 30 ) on litter size and plasma metabolites in gilts and sows. J. Anim. Sci. 93(11), 5291-5303.

Li, P., Yin, Y.L., Li, D.F., Kim, S.W., Wu, G., 2007. Amino acids and immune function. Br. J. Nutr. 98, 237-252.

Longenecker, J.B., Hause, N.L, 1959. Relationship between plasma Amino acids and composition of the ingested protein. Arch. Biochem. Biophys. 84, 46-59.

Lupi, A., Tenni, R., Rossi, A., Cetta, G., Forlino, A., 2008. Human prolidase and prolidase deficiency. Amino Acids 35, 739-752.

Meredith, C.N., Wen, Z.M., Bier, D.M., Matthews, D.E., Young, V.R., 1986. Lysine kinetics at graded lysine intakes in young men. Am. J. Clin. Nutr. 43, 787-794.

Michael, C.L., 1997. "Chapter 8. Body composition, the functions of food, metabolism and energy". Human nutrition in the developing world. Food and Nutrition Series - No. 29. Rome: Food and Agriculture Organization of the United Nations.

Miller, CS., Foulke, C.N., 1984. Use of lysine in treating recurrent oral Herpes simplex infections. Gen. Dent. 32, 490-493.

Millwar, D.J., Fereday, A., Gibson, N., Pacy, P.J., 1997. Aging, protein requirements, and protein turnover. Am. J. Clin. Nutr. 66(4), 774-786.

Morris, S.M., 2006. Arginine: beyond protein. Am. J. Clin. Nutr. 83(2), 508-512.

Newsholme, P., 2001. Why is L-glutamine metabolism important to cells of the immune system in health, postinjury, surgery or infection. Journal of Nutrition 131(9), 2515S-22S.; discussion 2523S-2524S.

Newsholme, P., Procopio, J., Lima, MM., Pithon-Curi, TC., Curi, R., 2003. Glutamine and glutamate-their central role in cell metabolism and function. Cell Biochemistry and Function 21(1), 1-9.

PDRhealth. http://www.pdrhealth.com/drug_info/ nmdrugprofiles/nutsupdrugs/lly_0166.shtml_[Accessed 03/01/2007].

Piatti, P.M., Monti, L.D., Valsecchi, G., Magni, F., Setola, E., Marchesi, F., Galli-Kienle, M., Pozza, G., Alberti, K.G., 2001. Long-term oral L-arginine administration improves peripheral and hepatic insulin sensitivity in type 2 diabetic patients. Diabetes Care 24(5), 875-880.

Raghavan, S.A., Dikshit, M., 2004. Vascular regulation by the L-arginine metabolites nitric oxide and agmatine. Pharmacol Res. 49(5), 397-414.

Rassaf, T., Kleinbongard, P., Kelm, M., 2006. The L-arginine nitric oxide pathway: avenue for a multiple level approach to assess vascular function. Biol. Chem. 387(10), 1347-1349.
Regulation (EC) No. 1924/2006 of the European Parliament and the Council of 20 Dec 2006 on nutrition and health claims made on foods, 2006. O.J. L404, 9-25.

Shils, M.E., Olson, J.A., Shike, M., Ross, A.C., Caballero, B., Cousins, R.J., eds. 2006. Modern Nutrition in Health and Disease, 10th ed. Philadelphia (PA): Lippincott Williams \& Wilkins.

Siani, A., Pagano, E., Iacone, R., Iacoviello, L., Scopacasa, F.,Strazzullo, P., 2000. Blood pressure and metabolic changes during dietary Larginine supplementation in humans. Am. J. Hypertens. 13, 547-551.

Souba, W.W., 1992. Glutamine Physiology, Biochemistry, and Nutrition in Critical Illness. Austin, TX: R.G. Landes Co. 67-69.

Suenaga, R., Tomonaga, S., Yamane, H., Kurauchi, I., Tsuneyoshi, Y., Sato, H., Denbow D. M., Furuse M. 2008. Intracerebroventricular injection of L-arginine induces sedative and hypnotic effects under an acute stress in neonatal chicks. Amino Acids 35, 139-146.

Tankersley, R.W., 1964. Amino acid requirements of herpes simplex virus in human cells. J. Bacteriol. 87, 609-661.

Torricelli, P., Fini, M., Giavaresi, G., Giardino, R., Gnudi, S., Nicolini, A., Carpi, A., 2002. L-Arginine and L-Lysine stimulation on cultured human osteoblasts. Biomedicine and Pharmacotherapy 56(10), 492-497.

Trumbo, P., Schlicker, S., Yates, A., Poos, M., 2002. Food and Nutrition Board of the Institute of Medicine, The National Academies. 2002. Dietary Reference Intakes for Energy, Carbohydrate, Fiber, Fat, Fatty Acids, Cholesterol, Protein, and Amino acids. J. Am. Diet Assoc. 102(11), 1621-1630.

U.S. National Medicines Library 2016; Herbs and Supplements; L-arginine. Available from: https://medlineplus.gov/ druginfo/natural/875.html [Accessed 01/08/2016].

Walsh, N.P., Blannin, A.K., Robson P.J, Gleeson, M., 1998. Glutamine, exercise and immune function. Sports Med. 26(3), 177-191.

Watford, M., 2008. Glutamine metabolism and function in relation to proline synthesis and the safety of glutamine and proline supplementation. J. Nutr. 138, 2003-2007.

Welbourne, T.C., 1995. Increased plasma bicarbonate and growth hormone after an oral glutamine loa, The American Journal of Clinical Nutrition 61(5), 1058-1061.

Wu, G., Bazer, FW., Tuo, W., Flynn, S.P. ,1996a. Unusual abundance of arginine and ornithine in porcine allantoic fluid. Biol. Reprod. 54, 1261-1265.

Wu, G., Meier, S.A., Knabe, D.A., 1996b. Dietary glutamine supplementation prevents jejunal atrophy in weaned pigs. J. Nutr. 126, 2578-2584.

Wu, G., Bazer, F.W., Davis, T.A., Kim S.W., Li P., Marc Rhoads J., Carey Satterfield M., Smith S.B., Spencer T.E., Yin Y, .2008. Arginine metabolism and nutrition in growth, health and disease. Amino Acids 37(1), 153-168.

Wu, G., 2009. Amino acids: metabolism, functions, and nutrition. Amino Acids 37(1), 1-17. 


\title{
Резиме
}

\section{Одобрени здравствени тврдења за амино киселини во/како додатоци на исхраната}

\author{
Ермира Красниќ ${ }^{1,2 *}$, Арбен Бошљаку³, Лидија Петрушевска Този ${ }^{1}$

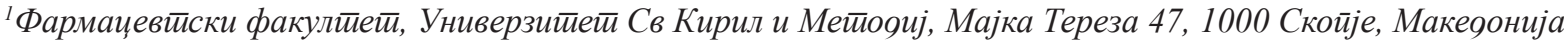 \\ ${ }^{2}$ Факулиеети за Меоииинско Технички Науки, Меоицински Универзииеей во Тирана, Албанија \\ ${ }^{3}$ Универзииетеи во Виена, Факулиетеи за Прироян инауки, Виена, Австирија
}

Клучни зборови: здравствени тврдења, амино киселини, додатоци, аргинин, глутамин, лизин

Додатоците на исхраната во Европската Унија прв пат се регулирани со Директивата 2002/46/ЕС, додека во 2006, EU ја усвои новата Регулатива за нутритивни и здравствени тврдења неменети за прехрамбените производи - Regulation 1924/2006. Во меѓувреме, во САД, диететските додатоци се дефинирани од Конгресот со Документ за додатоци во исхраната за здравје и едукација 1994.

Додатоците на исхраната може да покажат придобивки за здравјето на потрошувачите, но научниот преглед на достапните податоци мора да биде направен од компетентни институции. Во Европа, научните прегледи ги прави ЕФСА (European Food and Safety Authority), Панелот за Диететски Производи, Исхрана и Алергии (NDA Panel).

Амино киселините се предмет на многу научни истражувања, и многу од нив покажуваат влијание врз здравјето. Амино киселините имаат голема улога во многу функции на организмот, структура на клетките, транспорт и складирање на нутриентите, што води до главната цел на овој труд, која е обезбедување на податоци поврзани со влијанието на амино киселините кон здравствените придобивки, посебно за здравствените тврдења за аргинин (ерекција, васкуларен систем, интегрите на мускулите и функционирање на хематопетичниот имунсистем, сперматогенеза), глутамин (здравје на интестиналниот систем, подршка на гликогенското дополнување, зголемување на клеточното растење, имунитет, богатство на организмот, мускулна функција), лизин (кардиоваскуларен систем, зголемување на метаболизмот, коските, ткивата во организмот, функционирање на имуниот систем).

Меѓутоа, овие погодности се уште не се препознаени во медицинската наука во Европа и не се земаат сериозно во предвид, затоа што здравствените тврдења на прехранбените производи кои содржат амино киселини се уште се сметаат за нецелосно воспоставени во насока на поврзаноста причина - ефект. 
